\title{
Identification of biomarkers for lymph node metastasis in early-stage cervical cancer by tissue-based proteomics
}

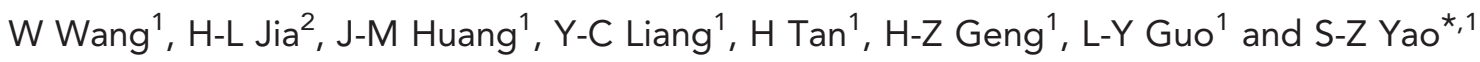 \\ ${ }^{1}$ Department of Obstetrics and Gynecology, the First Affiliated Hospital, Sun Yat-sen University, Guangzhou, Guangdong 510700, \\ China and ${ }^{2}$ Key Laboratory of Functional Protein Research of Guangdong Higher Education Institutes, Institute of Life and Health \\ Engineering, College of Life Science and Technology, Jinan University, Guangzhou, Guangdong 510632, China
}

Background: Pelvic lymph node metastasis (PLNM) is the key to determining the treatment and prognosis of early-stage cervical cancer (CC, I-IIst). The aim of this study was to identify biomarkers for PLNM of CC, I-Ilst.

Methods: Two-dimensional fluorescence difference gel electrophoresis and matrix-assisted laser desorption/ionisation-time-offlight mass spectrometry (MALDI-TOF/TOF MS) were used to identify differentially expressed proteins in primary CC, I-Ilst tissue with $(n=8)$ and without $(n=10)$ PLNM. The expression levels of three differential proteins (FABP5, HspB1, and MnSOD) were validated using western blotting and immunohistochemistry. An independent cohort of 105 CC, I-Ilst patients was analysed to assess the correlation of FABP5, HspB1, and MnSOD with clinicopathologic factors and clinical outcomes.

Results: Forty-one differential proteins were identified. Upregulation of FABP5, HspB1, and MnSOD in CC, I-Ilst with PLNM was confirmed and was significantly correlated with PLNM. FABP5, HspB1, and MnSOD were significant predictors of PLNM in univariate analysis. FABP5, HspB1, and lymphovascular space invasion (LVSI) were independent predictors of PLNM in multivariate analysis. Survival curves indicated that CC, I-Ilst patients with FABP5, HspB1, and MnSOD upregulation had poor prognosis.

Conclusions: FABP5, HspB1, and MnSOD may be potential biomarkers for PLNM of CC, I-Ilst and may have important roles in the pathogenesis of PLNM.

Globally, cervical cancer is the third most common cancer in women (Jemal et al, 2011). Pelvic lymph node metastasis (PLNM) is a critical factor for determining the individualised treatment and prognosis of cervical cancer, particularly in early-stage cervical cancer (CC, I-IIst) (Gien and Covens, 2009). The primary treatment for CC, I-IIst is either surgery or chemoradiotherapy. For patients with low risk of PLNM, surgical treatment (radical hysterectomy/conisation/trachelectomy plus lymph node (LN) dissection) can offer hope of fertility or function preservation for young patients and may avoid the long-term complications of chemoradiotherapy (Kobayashi et al, 2006; Rob et al, 2008; Cao et al, 2013). For patients with high risk of PLNM, primary chemoradiotherapy should be recommended. However, because it is difficult to clinically detect LN metastasis efficiently and reliably, some patients receive suboptimal treatment (first unnecessary surgery with adjuvant chemoradiotherapy) (Selman et al, 2008). Combining surgery and chemoradiotherapy leads to a higher morbidity, such as urological complications and lymph oedema (Landoni et al, 1997). Therefore, before the first treatment, stratification of CC, I-IIst patients based on PLNM is crucial to planning the optimal individualised treatment.

Imaging modalities, including computed tomography (CT), magnetic resonance imaging (MRI), and positron emission tomography (PET) scans are routinely used in preoperative examinations of PLNM. Nonetheless, these imaging modalities have relatively low sensitivity (Choi et al, 2006; Chou et al, 2006) for assessing PLNM in CC, I-IIst. Recently, laparoscopic lymphadenectomy was recommended before fertility-preserving surgery (Vercellino et al, 2012). However, lymphadenectomy is both invasive and associated with intraoperative and postoperative

*Correspondence: Professor S-Z Yao; E-mail: yszlfy@163.com

Received 3 September 2013; revised 9 December 2013; accepted 22 January 2014; published online 25 February 2014 
morbidity (van de Lande et al, 2012). Sentinel LN (SLN) biopsy is considered to be feasible for detecting the status of LN in earlystage cervical cancer (Plante et al, 2003). SLN biopsy can not only enhance the sensitivity and specificity of the diagnosis of PLNM but also reduce the extension of pelvic lymphadenectomy. Although it is less invasive than open and laparoscopic surgery, SLN biopsy still requires a general anaesthesia. At the present time, there are no known non-invasive and highly accurate detection methods that may be used to assess PLNM in CC, I-IIst before the first treatment. Therefore, an urgent need to identify biomarkers for PLNM in CC, I-IIst exists.

Previous studies for identifying PLNM-associated biomarkers in cervical cancer focused mainly on the transcriptomic (Huang et al, 2012) and genomic levels (Kim et al, 2008; Huang et al, 2011). However, alterations at the protein level can reflect cellular changes more accurately. Advances in bioinformatics and high-throughput technologies have provided powerful tools for unravelling the proteomic profile during PLNM progression. A recent study investigated sera from CC, I-IIst patients using surface-enhanced laser desorption/ionisation-time-of-flight mass spectrometry (SELDI-TOF-MS), and found that a model based on three differentially expressed peaks could determine LN status (Van Gorp et al, 2012). However, this study failed to identify the proteins represented by the three differentially expressed peaks. In contrast, our study was performed with primary CC, I-IIst tissue. Analysis of CC, I-IIst tissue has several potential advantages: first, there is an inherent link between the differential proteins and the tumour itself; second, we can take into account the contributions of the tumour microenvironment by testing protein expression in tissue, because the tumour microenvironment has a vital role in cancer metastasis (Langley and Fidler, 2011), and finally, primary cervical cancer tissue can be easily acquired by transvaginal biopsy before surgery. To our knowledge, there are no reports on the use of tissue-based proteomics to identify biomarkers associated with PLNM of CC, I-IIst.
The aim of this study was to identify biomarkers for PLNM of CC, I-IIst. We applied two-dimensional fluorescence difference gel electrophoresis (2D-DIGE) and matrix-assisted laser desorption/ ionisation-time-of-flight mass spectrometry (MALDI-TOF/TOF MS) to identify differential proteins between primary CC, I-IIst tissue with and without PLNM. Three differential proteins were further validated on an independent tissue cohort to evaluate their reliability in predicting PLNM of CC, I-IIst.

\section{MATERIALS AND METHODS}

Tissue sample collection. The study was approved by the Ethical Committee of the First Affiliated Hospital of Sun Yat-sen University (Guangzhou, China). Informed consent was obtained from each patient. Eighteen patients with early-stage cervical squamous cell cancer who underwent radical hysterectomy and pelvic lymphadenectomy at the First Affiliated Hospital of Sun Yat-sen University from January 2011 to September 2012 were recruited. None of these patients received preoperative radiation or chemotherapy, and none was documented as having other diseases per systematic examination before surgery. Based on the postoperative pathological examinations of pelvic LN (PLN), the CC, I-IIst cases were assigned into PLNM group $(n=8)$ and non-PLNM (NPLNM) group $(n=10)$. The clinicopathological characteristics of the tumour samples are shown in Table 1. There was no difference between the two groups in clinicopathological factors. To obtain tumour tissue, while on ice, each tissue sample was assessed and dissected by an experienced pathologist immediately after tumour resection. The pathologist then confirmed that each dissected tumour tissue block was composed of at least $80 \%$ tumour cells by frozen section examination. Dissected tissue samples were snap-frozen in liquid nitrogen with the shortest possible delay and were then stored at $-80^{\circ} \mathrm{C}$ until use.

For immunohistochemistry (IHC) validation, an independent tissue cohort with 105 early-stage cervical squamous cell cancer

\begin{tabular}{|c|c|c|c|c|c|c|c|c|c|}
\hline No. & Age (years) & $\begin{array}{l}\text { FIGO } \\
\text { stage }\end{array}$ & $\begin{array}{l}\text { Tumour } \\
\text { size }(\mathrm{cm})\end{array}$ & $\begin{array}{c}\text { Number of } \\
\text { positive PLN }\end{array}$ & $\begin{array}{l}\text { Number of } \\
\text { removed PLN }\end{array}$ & LVSI & Differentiation & $\begin{array}{c}\text { Pathological } \\
\text { type }\end{array}$ & $\begin{array}{l}\text { Stromal } \\
\text { invasion }\end{array}$ \\
\hline
\end{tabular}

Early-stage cervical cancer with PLNM

\begin{tabular}{|c|c|c|c|c|c|c|c|c|c|}
\hline 1 & 41 & Ila1 & 3 & 2 & 34 & Negative & $\mathrm{G} 2$ & Scc & $>1 / 2$ \\
\hline 2 & 56 & lb1 & 2.5 & 3 & 36 & Negative & $\mathrm{G} 2$ & Scc & $>1 / 2$ \\
\hline 3 & 42 & Ila2 & 5 & 2 & 32 & Negative & G3 & Scc & $>1 / 2$ \\
\hline 4 & 58 & Ila1 & 3.5 & 2 & 40 & Negative & G3 & $\mathrm{Scc}$ & $<1 / 2$ \\
\hline 5 & 39 & lb2 & 5 & 1 & 47 & Negative & G2 & Scc & $>1 / 2$ \\
\hline 6 & 58 & lb1 & 3 & 4 & 41 & Negative & G2 & Scc & $>1 / 2$ \\
\hline 7 & 67 & Ila2 & 5 & 13 & 43 & Positive & $\mathrm{G} 2$ & Scc & $>1 / 2$ \\
\hline 8 & 35 & lb1 & 3.5 & 7 & 35 & Negative & G3 & Scc & $<1 / 2$ \\
\hline
\end{tabular}

Early-stage cervical cancer without PLNM

\begin{tabular}{|c|c|c|c|c|c|c|c|c|c|}
\hline 1 & 40 & Ila2 & 5 & 0 & 35 & Negative & G2 & $\mathrm{Scc}$ & $>1 / 2$ \\
\hline 2 & 64 & lb1 & 2 & 0 & 34 & Negative & G2 & $\mathrm{Scc}$ & $<1 / 2$ \\
\hline 3 & 53 & Ila1 & 3.5 & 0 & 41 & Negative & G2 & $\mathrm{Scc}$ & $<1 / 2$ \\
\hline 4 & 32 & lb1 & 3 & 0 & 37 & Negative & G2 & $\mathrm{Scc}$ & $>1 / 2$ \\
\hline 5 & 42 & lb2 & 5 & 0 & 43 & Negative & G2 & $\mathrm{Scc}$ & $>1 / 2$ \\
\hline 6 & 42 & lb1 & 3 & 0 & 48 & Negative & G3 & $\mathrm{Scc}$ & $<1 / 2$ \\
\hline 7 & 49 & Ila1 & 3.5 & 0 & 30 & Negative & G2 & $\mathrm{Scc}$ & $>1 / 2$ \\
\hline 8 & 57 & lb1 & 3 & 0 & 51 & Positive & G2 & $\mathrm{Scc}$ & $>1 / 2$ \\
\hline 9 & 48 & Ila2 & 4.5 & 0 & 46 & Negative & G3 & $\mathrm{Scc}$ & $>1 / 2$ \\
\hline 10 & 52 & Ila1 & 3 & 0 & 48 & Negative & G3 & $\mathrm{Scc}$ & $<1 / 2$ \\
\hline
\end{tabular}

Abbreviations: $\mathrm{FIGO}=$ the International Federation of Gynaecology and Obstetrics; LVSI=lymphovascular space invasion; PLN = pelvic lymph node; PLNM = pelvic lymph node metastasis Scc = squamous cell carcinoma. 
samples (22 PLNM, 83 NPLNM) was used (Supplementary Table S1). This cohort of paraffin-embedded tissue material was collected from the archives of the pathology department at the First Affiliated Hospital of Sun Yat-sen University. Surgeries were performed between 2003 and 2007. None of the patients received radiotherapy and/or chemotherapy before surgery. All specimens were handled according to legal and ethical standards.

Protein sample preparation. Tissue $(\sim 100 \mathrm{mg})$ was mechanically homogenised in lysis buffer ( $2 \mathrm{M}$ thiourea, $7 \mathrm{M}$ urea, $30 \mathrm{~mm}$ Tris, $4 \%$ $w / v$ CHAPS) on ice. These homogenates were sonicated intermittently and then separated by centrifugation at 20, 000 r.p.m. for $40 \mathrm{~min}$ at $4^{\circ} \mathrm{C}$. The supernatant was collected. To purify the protein extract and to quantify the final protein concentration, a 2-D clean-up kit (Amersham Biosciences, Buckinghamshire, UK) and a 2-D Quant Kit (GE Healthcare, London, UK) were used sequentially according to the manufacturers' instructions. Equal amounts of proteins extracted from the same group were pooled for DIGE analysis.

Protein sample labelling with CyDye. CyDye DIGE fluors (Cy2, $\mathrm{Cy} 3$, and $\mathrm{Cy} 5$ ) were used to label the protein extracts following the manufacturer's protocol (GE Healthcare). The internal standard pool was generated by combining equal amounts of extracts from all samples, labelled with Cy2. Protein extracts from the PLNM and NPLNM groups were labelled with Cy3 and Cy5, respectively. The labelling reaction was performed on ice for $30 \mathrm{~min}$ in darkness, and was then quenched with $10 \mathrm{~mm}$ lysine for $10 \mathrm{~min}$ on ice under dark conditions. The labelled samples were then mixed and prepared for the following steps.

Two-dimensional electrophoresis. After rehydration, the labelled protein mixture for each gel was applied to an immobilised $\mathrm{pH}$ gradient (IPG) strip (24 cm, pH 3-10 NL; GE Healthcare). Isoelectric focusing (IEF) was performed following the manufacturer's instructions with an Ettan IPGphor II System (GE Healthcare). After IEF, the proteins were reduced with equilibration buffer containing $2 \%$ $w / v$ dithiothreitol (DTT) for $15 \mathrm{~min}$. The proteins were then alkylated with equilibration buffer containing 2.5\% $w / v$ iodoacetamide for $15 \mathrm{~min}$. The second dimension of electrophoresis was conducted using an Ettan DALT-VI system (GE Healthcare).

Gel image acquisition and analysis. The Typhoon 9400 imager (GE Healthcare) was used to visualise labelled proteins at excitation/emission wavelengths of 488/520 nm (cy2), 532/580 nm (cy3), and 633/670 nm (cy5). DeCyder software (V6.0, GE Healthcare) was used to analyse the 2-D DIGE gel images. Protein spots with significant differences in abundance (increased or decreased more than $>1.5$-fold) were selected for further analysis.

Spot picking and enzymatic digestion. Using an Ettan Spot Handling Workstation (GE Healthcare), the selected protein spots were automatically picked up and treated. The protein spots were washed with $25 \mathrm{~mm} \mathrm{NH}_{4} \mathrm{HCO}_{3}$ and $50 \%$ acetonitrile and were then digested with $8 \mathrm{ng} \mathrm{l}^{-1}$ trypsin solution (mass spectrometry grade; Promega, Madison, WI, USA) in $25 \mathrm{~mm} \mathrm{NH}_{4} \mathrm{HCO}_{3}$ for $16 \mathrm{~h}$ at $37^{\circ} \mathrm{C}$. After digestion, the tryptic peptides were extracted with $60 \%$ $(\mathrm{v} / \mathrm{v})$ acetonitrile and $0.1 \%(\mathrm{v} / \mathrm{v})$ trifluoroacetic acid (TFA). Finally, the tryptic peptides were dissolved in $4 \mathrm{mg} \mathrm{ml}^{-1} 4$-hydroxy-alphacyanocinnamic acid matrix in $70 \%(\mathrm{v} / \mathrm{v})$ acetonitrile and $0.1 \%(\mathrm{v} / \mathrm{v})$ TFA and were spotted on the target plate.

MALDI-TOF/TOF MS analysis. In positive ion reflector mode, an Ultraflex III MALDI-TOF/TOF MS (Bruker, Karlsruhe, BadenWürttemberg, Germany) was used to perform MS analysis. Four of the most intense ion signals were automatically chosen as precursors for MS/MS acquisition, excluding the matrix ion signals and trypsin autolysis peaks. MASCOT Version 2.2 (Matrix Science, London, UK) and Biotools software (Version 3.2, Bruker) were used to search the MS/MS spectra combined peptide mass fingerprint in the NCBInr database. The following search criteria were used: Homo sapiens, trypsin cleavage, oxidation of methionines allowed as variable modification, one missed cleavage allowed, carbamidomethylation as fias modification, peptide mass tolerance at $75 \mathrm{ppm}$, and fragment tolerance at $0.5 \mathrm{Da}$. A successfully identified protein had the following parameters: ion score confidence interval (CI\%) for PMF and MS/MS data $\geqslant 95 \%$, distinct sequences identified in MS/MS analysis $\geqslant 2$ and peptide count (hit) $\geqslant 4$.

Differential proteins categorisation and network modelling. The differential proteins were assorted using the protein analysis through evolutionary relationships (PANTHER) system (http:// www.pantherdb.org). The PANTHER ontology is a highly controlled vocabulary categorised according to biological process, protein class, and molecular function.

To establish an interaction map among the differential proteins, we used Pathway Studio 5.0 software (Ariadne Genomics, Rockville, MD, USA), a text-mining tool that can construct protein interaction networks and pathways. It includes protein-protein interactions, pathway components, proteins and their cellular processes, and functional classes. In this study, we selected the shortest path analysis.

Western blotting. Western blotting was performed on the same set of samples used in the DIGE analysis. Briefly, $50 \mu \mathrm{g}$ pooled protein extracts of each group were fractionated by $10 \%$ SDS-PAGE and transferred to a PVDF membrane as previously described (Li et al, 2013). The signal was detected with an enhanced chemiluminescence (ECL) plus kit (Milipore, Bedford, MA, USA). Anti-manganese superoxide dismutase (anti-MnSOD) $(1: 2000)$, anti-heat shock protein B1 (anti-HspB1) $(1: 1000)$, anti-fatty acid binding protein 5 (anti-FABP5) (1:1000), and anti-glycerol-3-phosphate dehydrogenase (anti-GAPDH) $(1: 1000)$ were used. All of these antibodies were rabbit polyclonal antibodies and were purchased from Abcam, Inc. (Cambridge, MA, USA).

Immunohistochemistry. Immunohistochemistry staining was performed using various primary antibodies including anti-

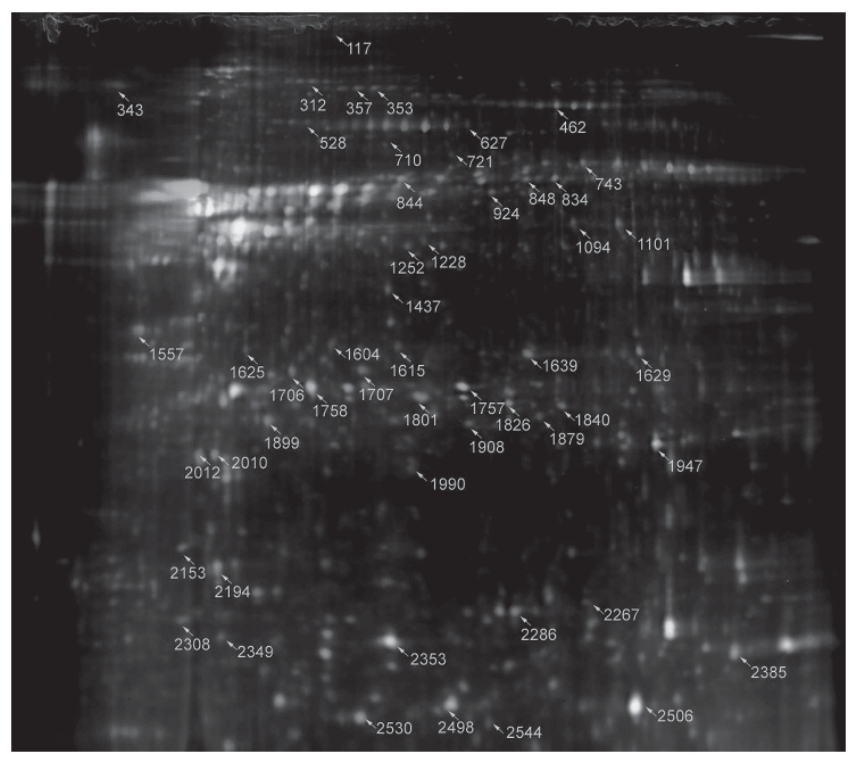

Figure 1. Representative DIGE gel image of differentially expressed proteins in primary early-stage cervical cancer with and without PLNM. Proteins extracted from the two groups were labelled with Cy3 (green, PLNM) and Cy5 (red, NPLNM). An internal standard (a mixture of PLNM and NPLNM CC, I-Ilst samples) was labelled with Cy2 (blue). The yellow arrow indicates the significantly differentially expressed protein points in the PLNM and NPLNM groups. The number in the figure corresponds to the number shown in Table 2. The full colour version of this figure is available at British Journal of Cancer online. 
MnSOD (1:600), anti-HspB1 (1:1200), and anti-FABP5 (1:600) as previously described (Pang et al, 2010). These antibodies are the same as those used in western blotting. In negative controls, primary antibodies were omitted. Two experienced pathologists assessed the immunostaining in a blinded fashion as described previously (Cheng et al, 2008). The results were scored by adding the staining intensity $(0=$ no, $1=$ weak, $2=$ moderate, $3=$ strong staining) and the staining area $(0=$ no, $1=<30 \%, 2=$ between $30 \%$ and $60 \%, 3=$ between 60 and $100 \%$ stained cells). For statistical analysis, the immunostaining scores (ranging from 0 to 6 )

Table 2. Differential proteins between early-stage cervical cancer with and without PLNM identified by MALDI-TOF/TOF MS

\begin{tabular}{|c|c|c|c|c|c|c|c|}
\hline $\begin{array}{l}\text { Master } \\
\text { no. }\end{array}$ & $\begin{array}{l}\text { Accession } \\
\text { no. }\end{array}$ & $\mathrm{Mr}$ & PI & $\begin{array}{l}\text { Mascot } \\
\text { score }\end{array}$ & $\begin{array}{l}\text { Coverage } \\
\text { (\%) }\end{array}$ & $\begin{array}{c}\text { Fold } \\
\text { change } \\
\text { (PLNM/ } \\
\text { NPLNM) }\end{array}$ & Protein name \\
\hline 117 & P12110 & 109709 & 5.85 & 96 & $14 \%$ & 2.19 & COL6A2 Isoform 2C2 of Collagen alpha-2(VI) chain \\
\hline 312 & P02679 & 50092 & 5.7 & 68 & $10 \%$ & -4.05 & FGG Isoform Gamma-A of Fibrinogen gamma chain \\
\hline 343 & Q05707 & 92740 & 4.70 & 98 & $18 \%$ & 4.67 & COL14A1 $93 \mathrm{kDa}$ protein \\
\hline 353 & P02679 & 50092 & 5.7 & 124 & $18 \%$ & -6.04 & FGG Isoform Gamma-A of Fibrinogen gamma chain \\
\hline 357 & P02679 & 50092 & 5.7 & 77 & $10 \%$ & -8.02 & FGG Isoform Gamma-A of Fibrinogen gamma chain \\
\hline 462 & P02787 & 79294 & 6.81 & 359 & $46 \%$ & 1.53 & TF Serotransferrin \\
\hline 528 & BOYJC5 & 26956 & 4.68 & 70 & $26 \%$ & -5.45 & VIM Vimentin variant 4 \\
\hline 627 & Q9UBG3 & 53730 & 5.73 & 84 & $21 \%$ & 3.68 & CRNN Cornulin \\
\hline 710 & B4E3Q9 & 101217 & 5.35 & 86 & $15 \%$ & -1.52 & VCL cDNA FLJ59659, highly similar to Vinculin \\
\hline 721 & Q96AX9 & 82990 & 7.41 & 71 & $6 \%$ & -2.49 & MIB2 E3 ubiquitin-protein ligase MIB2 isoform 5 \\
\hline 743 & P02675 & 56577 & 8.54 & 80 & $18 \%$ & -3.2 & FGB Fibrinogen beta chain \\
\hline 834 & B4DRRO & 58088 & 8.09 & 210 & $36 \%$ & -3.53 & KRT6A cDNA FLJ53910, highly similar to Keratin, type II cytoskeletal 6A \\
\hline 844 & P13647 & 62568 & 7.59 & 335 & $40 \%$ & -2.32 & KRT5 Keratin, type II cytoskeletal 5 \\
\hline 848 & B4DRRO & 58088 & 8.09 & 368 & $47 \%$ & -2.86 & KRT6A cDNA FLJ53910, highly similar to Keratin, type II cytoskeletal 6A \\
\hline 924 & B4DRRO & 58088 & 8.09 & 388 & $53 \%$ & -7.89 & KRT6A cDNA FLJ53910, highly similar to Keratin, type II cytoskeletal 6A \\
\hline 1094 & B4E1D3 & 50436 & 8.22 & 148 & $24 \%$ & -5.97 & FGB fibrinogen beta chain isoform 2 preproprotein \\
\hline 1101 & B4E1D3 & 50436 & 8.22 & 251 & $43 \%$ & -5.66 & FGB fibrinogen beta chain isoform 2 preproprotein \\
\hline 1228 & B4DW52 & 38950 & 5.19 & 84 & $13 \%$ & 1.59 & ACTB cDNA FLJ55253, highly similar to Actin, cytoplasmic 1 \\
\hline 1252 & B4E1D3 & 50436 & 8.22 & 192 & $39 \%$ & -2.02 & FGB fibrinogen beta chain isoform 2 preproprotein \\
\hline 1437 & P17706 & 41363 & 5.98 & 69 & $10 \%$ & 2.46 & PTPN2 tyrosine-protein phosphatase non-receptor type 2 \\
\hline 1557 & P67936 & 28619 & 4.67 & 251 & $42 \%$ & 2.16 & TPM4 Isoform 1 of Tropomyosin alpha-4 chain \\
\hline 1604 & B4E3A4 & 40116 & 5.23 & 169 & $21 \%$ & -3.84 & cDNA FLJ57283, highly similar to Actin, cytoplasmic 2 \\
\hline 1615 & P02679 & 50092 & 5.7 & 109 & $17 \%$ & -4.69 & FGG Isoform Gamma-A of Fibrinogen gamma chain \\
\hline 1625 & P30101 & 13739 & 6.78 & 131 & $33 \%$ & 2.52 & PDIA3 $14 \mathrm{kDa}$ protein \\
\hline 1629 & P04075 & 39851 & 8.3 & 63 & $11 \%$ & 2.05 & ALDOA Fructose-bisphosphate aldolase A \\
\hline 1639 & E7EOV7 & 58718 & 6.6 & 333 & $28 \%$ & -7.69 & KRT6C Uncharacterized protein \\
\hline 1706 & P14618 & 58538 & 7.6 & 103 & $13 \%$ & 2.89 & PKM2 Isoform M1 of Pyruvate kinase isozymes M1/M2 \\
\hline 1707 & P49761 & 74267 & 9.94 & 73 & $8 \%$ & -4.3 & CLK3 Isoform 4 of Dual specificity protein kinase CLK3 \\
\hline 1757 & P04792 & 22826 & 5.98 & 305 & $42 \%$ & 15.22 & HSPB1 Heat shock protein beta-1 \\
\hline 1758 & P60709 & 42052 & 5.29 & 197 & $39 \%$ & 2.06 & ACTB Actin, cytoplasmic 1 \\
\hline 1801 & P13647 & 23267 & 4.82 & 343 & $49 \%$ & -3.88 & KRT5 Keratin, type II cytoskeletal 5 \\
\hline 1826 & P02768 & 23414 & 5.93 & 164 & $47 \%$ & 1.6 & ALB $23 \mathrm{kDa}$ protein \\
\hline 1840 & E7EUE8 & 56065 & 5.95 & 247 & $31 \%$ & -3.51 & KRT6A Uncharacterized protein \\
\hline 1879 & P04792 & 22826 & 5.98 & 238 & $51 \%$ & 5.11 & HSPB1 Heat shock protein beta-1 \\
\hline 1899 & B4DRRO & 58088 & 8.09 & 251 & $29 \%$ & -2.44 & KRT6A cDNA FLJ53910, highly similar to Keratin, type II cytoskeletal 6A \\
\hline 1908 & E9PH29 & 26107 & 7.04 & 74 & $14 \%$ & 2.27 & $\begin{array}{l}\text { PRDX3 thioredoxin-dependent peroxide reductase, mitochondrial } \\
\text { isoform b }\end{array}$ \\
\hline 1947 & P04179 & 24878 & 8.35 & 169 & $44 \%$ & 2.57 & SOD2 Superoxide dismutase $[\mathrm{Mn}]$, mitochondrial \\
\hline 1990 & P09211 & 23569 & 5.43 & 171 & $43 \%$ & 2.27 & GSTP1 Glutathione S-transferase P \\
\hline 2010 & E7EUE8 & 56065 & 5.95 & 216 & $23 \%$ & -2.57 & KRT6A Uncharacterized protein \\
\hline 2012 & B4DNH8 & 2182 & 5.98 & 75 & $37 \%$ & -1.53 & cDNA FLJ59138, highly similar to Annexin A2 \\
\hline 2153 & B4DNG6 & 18212 & 4.99 & 90 & $44 \%$ & 2.68 & ANXA5 ANXA5 Uncharacterized protein \\
\hline 2194 & G5E9R0 & 13907 & 5.24 & 246 & $54 \%$ & 1.51 & ACTB $14 \mathrm{kDa}$ protein \\
\hline 2267 & P25398 & 14905 & 6.81 & 85 & $25 \%$ & 2.8 & RPS12 40S ribosomal protein S12 \\
\hline 2286 & Q01469 & 15497 & 6.6 & 84 & $57 \%$ & 7.49 & FABP5 Fatty acid-binding protein, epidermal \\
\hline 2308 & P20674 & 16923 & 6.3 & 100 & $11 \%$ & 3.46 & COX5A Cytochrome c oxidase subunit $5 \mathrm{~A}$, mitochondrial \\
\hline 2349 & P09382 & 15048 & 5.34 & 311 & $62 \%$ & 1.6 & LGALS1 Galectin-1 \\
\hline 2353 & P06702 & 13291 & 5.71 & 101 & $90 \%$ & -2.47 & S100A9 Protein S100-A9 \\
\hline 2385 & 094964 & 185512 & 6.15 & 63 & $7 \%$ & 2.84 & KIAA0889 Isoform 2 of Uncharacterized protein KIAA0889 \\
\hline 2498 & P31949 & 11847 & 6.56 & 65 & $28 \%$ & 1.51 & S100A11 Protein S100-A11 \\
\hline 2506 & P05109 & 10885 & 6.51 & 194 & $67 \%$ & -2.17 & S100A8 Protein S100-A8 \\
\hline 2530 & Q9H628 & 7191 & 9.06 & 64 & $48 \%$ & 1.53 & RERGL 7 kDa protein \\
\hline 2544 & F8VY1 & 7837 & 9.81 & 62 & $31 \%$ & 2.6 & CDK4 Uncharacterized protein \\
\hline
\end{tabular}


were evaluated and a cut-off was determined. The samples were divided accordingly into low- and high-staining groups. For HspB1, a staining score of 4 was defined as the cutoff. For MnSOD and FABP5, a staining score of 3 was defined as the cutoff.

Statistical analysis. Statistical analyses were performed using SPSS 13.0 (SPSS Inc., Chicago, IL, USA) and MedCalc statistical software (MedCalc Software, Mariakerke, Belgium). The relationships between the FABP5, HspB1, and MnSOD expression levels and clinicopathological factors were evaluated using the Pearson $\chi^{2}$ test or Fisher's exact test. Logistic regression analyses (univariate and stepwise multivariate) were used to determine variable predictability of PLNM. Receiver operating characteristic (ROC) analysis was used to test the discriminatory power of measured markers. The Kaplan-Meier method was used to construct relapse-free probability curves and overall survival curves, and the curves were compared by the log-rank test. $P<0.05$ was considered to be statistically significant.

\section{RESULTS}

Identification of differential proteins in primary early-stage cervical cancer with and without PLNM by proteomic analysis. Protein extracts from tissue homogenates were subjected to DIGE analysis. Figure 1 shows a typical DIGE gel image. After visual review, 52 differential protein spots with at least a 1.5 -fold discrepancy between the two groups were selected for MALDITOF/TOF MS analysis. In total, 41 differentially expressed proteins (26 upregulated and 15 downregulated) were successfully identified (Table 2). Some proteins appeared as multiple spots in DIGE, likely due to their isoforms and/or modifications.

Differential proteins categorisation and network modelling. The differential proteins were classified according to biological processes, molecular functions, and protein classes using the PANTHER system (Figure 4). The proteins were classified into 23 groups based on protein classes, including signalling molecules (14\%), calcium-binding proteins (8\%), cell adhesion molecules (6\%), oxidoreductases (4\%), and so on. Most of the proteins participated in the metabolic (15\%), cellular (14\%), and cell communication processes (12\%). The proteins were also involved in other biological processes, such as the immune responses, cell adhesion, the generation of energy, apoptosis and cellular component organisation. Regarding molecular function, the proteins were divided into five categories: (a) catalytic activity (34\%), (b) binding (30\%), (c) structural molecule activity (21\%), (d) receptor activity (6\%), and (e) motor activity (3\%).

To explore the associations between differentially expressed proteins, we constructed a protein network with Pathway Studio
A
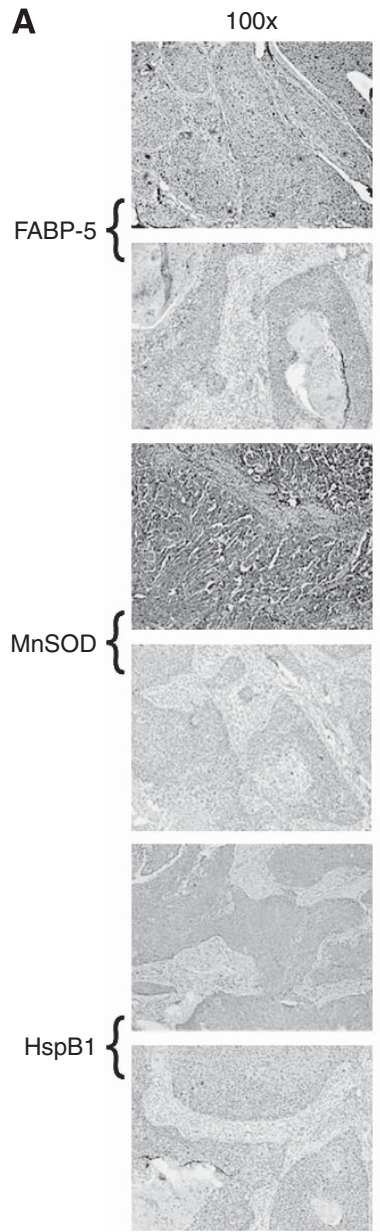

$200 x$
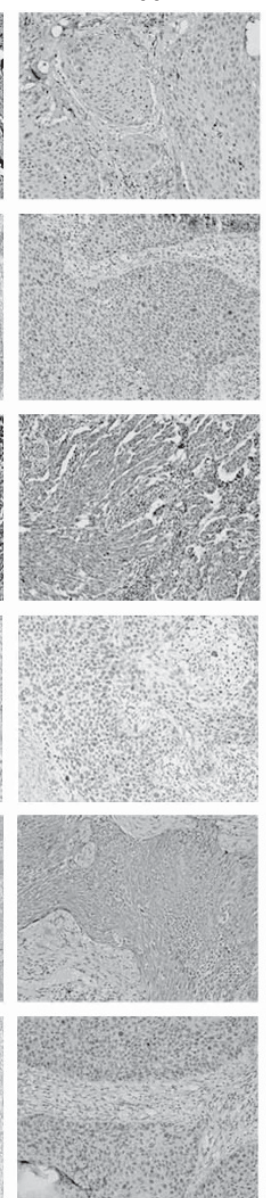

$400 x$

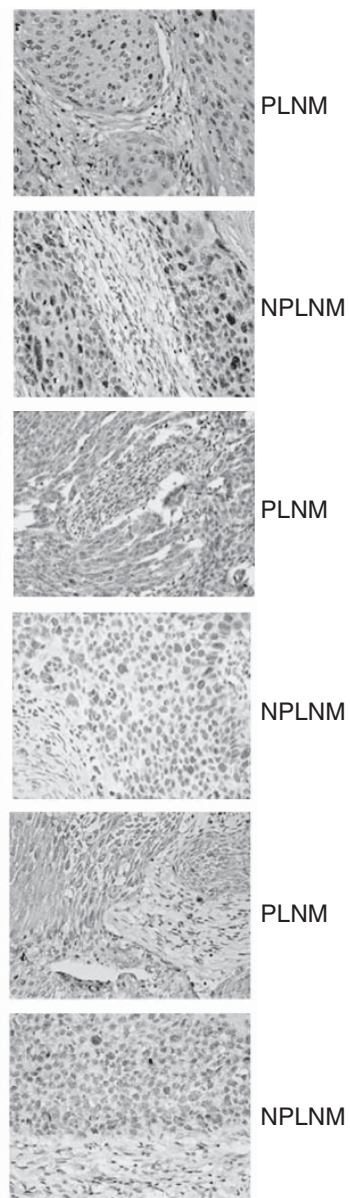

B
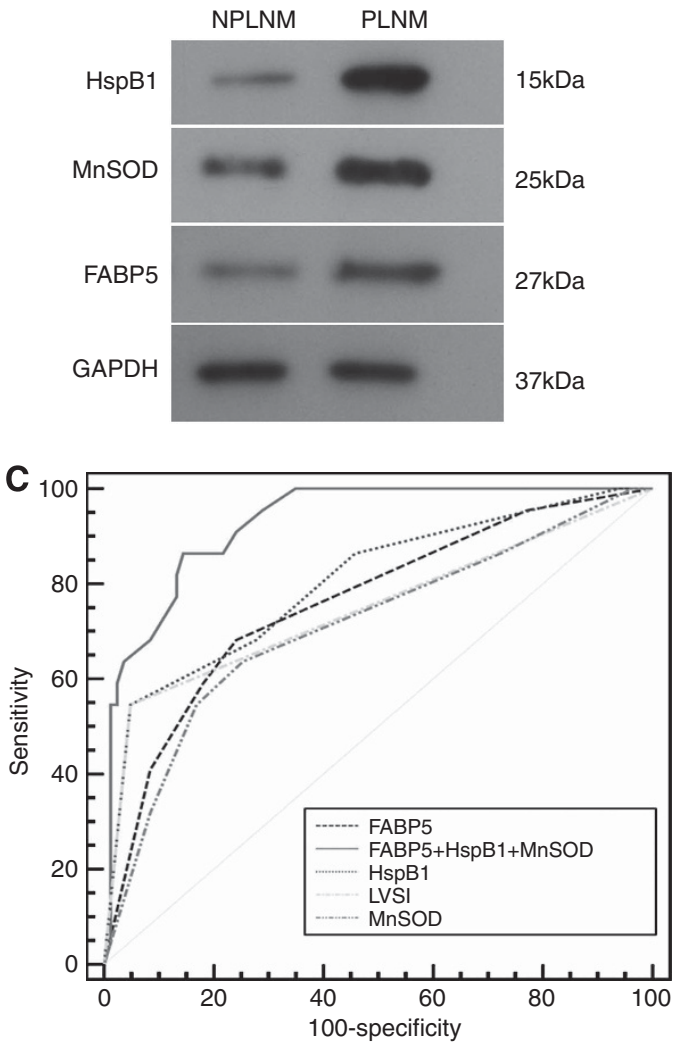

Figure 2. Validation of FABP5, HspB1, and MnSOD expression in early-stage cervical cancer with and without PLNM, and their discriminatory power as proteomic biomarkers. (A) Representative results of immunohistochemical staining of FABP5, HspB1, and MnSOD in early-stage cervical cancer with and without PLNM. (B) Representative results of western blotting of FABP5, HspB1, and MnSOD in early-stage cervical cancer with and without PLNM. GAPDH is used as an internal loading control. (C) ROC curves of FABP5, HspB1, MnSOD, and LVSI as markers to differentiate PLNM in early-stage cervical cancer (HspB1 AUC =0.803; MnSOD AUC =0.713; FABP5 AUC =0.761; LVSI AUC =0.749; the combination of FABP5, HspB1, and MnSOD AUC =0.929). 
5.0 software. Complex interactions between mitochondrial, nuclear, cytoplasmic, and extracellular proteins were present in the prediction network (Supplementary Figure S1). Further research is needed to explore the role of these proteins and their interaction pathways in the pathogenesis of PLNM in CC, I-IIst.

Validation of differential proteins by western blotting. To further confirm the proteomic results, western blotting was performed to examine the expression levels of FABP5, HspB1, and MnSOD in the same pooled protein extracts used in the DIGE analysis. The expression levels of the three proteins were higher in the PLNM group than in the NPLNM group (Figure 2B). This validation result was consistent with the DIGE analysis.

Validation of differential proteins by IHC. Immunohistochemical staining was performed to examine the expression levels of FABP5, HspB1, and MnSOD in an independent tissue cohort of primary CC, I-IIst. Semi-quantitative analysis showed that the PLNM group had significantly higher expression of FABP5, HspB1, and MnSOD than the NPLNM group (Table 3, Figure 2A).
Next, the correlation of FABP5, HspB1, and MnSOD with clinicopathological factors was analysed (Table 3). HspB1 was significantly correlated with PLNM $(P<0.001)$. MnSOD was significantly correlated with PLNM $(P=0.006)$, lymphovascular space invasion $(\mathrm{LVSI})(P=0.01)$, and stromal invasion $(P=0.002)$. FABP5 was significantly correlated with PLNM $(P<0.001)$ and LVSI $(P=0.001)$. No significant correlations were identified between the expression of the three proteins and other clinicopathological characteristics, including age, tumour size, tumour differentiation, International Federation of Gynaecology and Obstetrics (FIGO) stage, parametrial invasion, and vaginal invasion.

Correlations of FABP5, HspB1, and MnSOD expression with PLNM. Univariate logistic regression analysis revealed that tumour size $(P=0.003)$, LVSI $(P<0.001)$, stromal invasion $(P=0.006)$, MnSOD $(P=0.011)$, HspB1 $(P=0.001)$, and FABP5 $(P<0.001)$ were significant predictors of PLNM (Table 4$)$. Stepwise multivariate logistic regression analysis indicated that LVSI $(P=0.001)$, HspB1 $(P=0.013)$, and FABP5 $(P=0.018)$ were independent predictors of PLNM in patients with CC, I-IIst (Table 4).

\begin{tabular}{|c|c|c|c|c|c|c|c|c|c|c|}
\hline & $N$ & & HspB1 & & & MnSOD & & & FABP5 & \\
\hline & 105 & $\begin{array}{c}\text { Low } \\
(0-4) 67\end{array}$ & $\begin{array}{l}\text { High } \\
(5-6) 38\end{array}$ & $P$-value & $\begin{array}{c}\text { Low } \\
(0-3) 69\end{array}$ & $\begin{array}{l}\text { High } \\
(4-6) 36\end{array}$ & $P$-value & $\begin{array}{c}\text { Low } \\
(0-3) 70\end{array}$ & $\begin{array}{l}\text { High } \\
(4-6) 35\end{array}$ & $P$-value \\
\hline Age (years) & - & - & - & 0.761 & - & - & 0.918 & - & - & 0.121 \\
\hline $\begin{array}{l}\leqslant 35 \\
>35\end{array}$ & $\begin{array}{l}21 \\
84\end{array}$ & $\begin{array}{l}14 \\
53\end{array}$ & $\begin{array}{r}7 \\
31\end{array}$ & - & $\begin{array}{l}14 \\
55\end{array}$ & $\begin{array}{l}7 \\
29\end{array}$ & $\begin{array}{l}- \\
-\end{array}$ & $\begin{array}{l}17 \\
53\end{array}$ & $\begin{array}{r}4 \\
31\end{array}$ & $\begin{array}{l}- \\
-\end{array}$ \\
\hline FIGO stage & - & - & & 0.205 & - & - & 0.745 & - & - & 0.076 \\
\hline $\begin{array}{l}\text { la2 } \\
\text { lb1 } \\
\text { lb2 } \\
\text { Ila1 } \\
\text { Ila2 }\end{array}$ & $\begin{array}{l}12 \\
37 \\
22 \\
16 \\
18\end{array}$ & $\begin{array}{c}9 \\
28 \\
13 \\
8 \\
9\end{array}$ & $\begin{array}{l}3 \\
9 \\
9 \\
8 \\
9\end{array}$ & $\begin{array}{l}- \\
- \\
- \\
- \\
-\end{array}$ & $\begin{array}{l}10 \\
24 \\
14 \\
10 \\
11\end{array}$ & $\begin{array}{c}2 \\
13 \\
8 \\
6 \\
7\end{array}$ & $\begin{array}{l}- \\
- \\
- \\
-\end{array}$ & $\begin{array}{r}12 \\
24 \\
15 \\
10 \\
9\end{array}$ & $\begin{array}{r}0 \\
13 \\
7 \\
6 \\
9\end{array}$ & $\begin{array}{l}- \\
- \\
- \\
- \\
-\end{array}$ \\
\hline Tumour size $(\mathrm{cm})$ & - & - & - & 0.059 & - & - & 0.586 & - & - & 0.256 \\
\hline $\begin{array}{l}\leqslant 4 \\
>4\end{array}$ & $\begin{array}{l}65 \\
40\end{array}$ & $\begin{array}{l}46 \\
21\end{array}$ & $\begin{array}{l}19 \\
19\end{array}$ & $\begin{array}{l}- \\
-\end{array}$ & $\begin{array}{l}44 \\
25\end{array}$ & $\begin{array}{l}21 \\
15\end{array}$ & - & $\begin{array}{l}46 \\
24\end{array}$ & $\begin{array}{l}19 \\
16\end{array}$ & $\begin{array}{l}- \\
-\end{array}$ \\
\hline PLNM & - & - & - & $<0.001$ & - & - & $<0.001$ & - & - & $<0.001$ \\
\hline $\begin{array}{l}\text { Positive } \\
\text { Negative }\end{array}$ & $\begin{array}{l}22 \\
83 \\
\end{array}$ & $\begin{array}{c}7 \\
60\end{array}$ & $\begin{array}{l}15 \\
23 \\
\end{array}$ & - & $\begin{array}{l}10 \\
58 \\
\end{array}$ & $\begin{array}{l}12 \\
25 \\
\end{array}$ & - & $\begin{array}{r}6 \\
64\end{array}$ & $\begin{array}{l}16 \\
19 \\
\end{array}$ & $\begin{array}{l}- \\
-\end{array}$ \\
\hline LVSI & - & - & - & 0.287 & - & - & 0.01 & - & - & 0.001 \\
\hline $\begin{array}{l}\text { Positive } \\
\text { Negative }\end{array}$ & $\begin{array}{l}16 \\
89\end{array}$ & $\begin{array}{c}8 \\
59\end{array}$ & $\begin{array}{r}8 \\
30\end{array}$ & - & $\begin{array}{r}6 \\
63\end{array}$ & $\begin{array}{l}10 \\
26\end{array}$ & $\begin{array}{l}- \\
-\end{array}$ & $\begin{array}{r}5 \\
65\end{array}$ & $\begin{array}{l}11 \\
24\end{array}$ & $\begin{array}{l}- \\
-\end{array}$ \\
\hline Differentiation & - & - & - & $0.366^{\mathrm{a}}$ & - & - & $0.555^{a}$ & - & - & $1^{\mathrm{a}}$ \\
\hline $\begin{array}{l}\mathrm{G} 1 \\
\mathrm{G} 2 \\
\mathrm{G} 3\end{array}$ & $\begin{array}{r}6 \\
37 \\
62\end{array}$ & $\begin{array}{c}4 \\
27 \\
36\end{array}$ & $\begin{array}{r}2 \\
10 \\
26\end{array}$ & $\begin{array}{l}- \\
- \\
-\end{array}$ & $\begin{array}{r}3 \\
26 \\
40\end{array}$ & $\begin{array}{c}3 \\
11 \\
22\end{array}$ & $\begin{array}{l}- \\
- \\
-\end{array}$ & $\begin{array}{r}4 \\
25 \\
41\end{array}$ & $\begin{array}{r}2 \\
12 \\
21\end{array}$ & $\begin{array}{l}- \\
- \\
-\end{array}$ \\
\hline Stomal invasion & - & - & - & - & - & 0.002 & - & - & - & 0.096 \\
\hline $\begin{array}{l}\leqslant 1 / 2 \\
>1 / 2\end{array}$ & $\begin{array}{l}48 \\
57\end{array}$ & $\begin{array}{l}35 \\
32\end{array}$ & $\begin{array}{l}13 \\
25\end{array}$ & $\begin{array}{l}- \\
-\end{array}$ & $\begin{array}{l}39 \\
29\end{array}$ & $\begin{array}{c}9 \\
28\end{array}$ & - & $\begin{array}{l}36 \\
34\end{array}$ & $\begin{array}{l}12 \\
23\end{array}$ & - \\
\hline Parametrial invasion & - & - & - & 1 & - & - & 1 & - & - & 0.064 \\
\hline $\begin{array}{l}\text { Positive } \\
\text { Negative }\end{array}$ & $\begin{array}{r}9 \\
96\end{array}$ & $\begin{array}{c}6 \\
61\end{array}$ & $\begin{array}{r}3 \\
35\end{array}$ & - & $\begin{array}{r}6 \\
63\end{array}$ & $\begin{array}{c}3 \\
33\end{array}$ & $\begin{array}{l}- \\
-\end{array}$ & $\begin{array}{r}3 \\
67\end{array}$ & $\begin{array}{r}6 \\
29\end{array}$ & $\begin{array}{l}- \\
-\end{array}$ \\
\hline Vaginal invasion & - & - & - & 0.948 & - & - & 0.184 & - & - & 0.37 \\
\hline $\begin{array}{l}\text { Positive } \\
\text { Negative }\end{array}$ & $\begin{array}{l}19 \\
86\end{array}$ & $\begin{array}{l}12 \\
55\end{array}$ & $\begin{array}{r}7 \\
31\end{array}$ & - & $\begin{array}{l}10 \\
59\end{array}$ & $\begin{array}{c}9 \\
27\end{array}$ & $\begin{array}{l}- \\
-\end{array}$ & $\begin{array}{l}11 \\
59\end{array}$ & $\begin{array}{r}8 \\
27\end{array}$ & $\begin{array}{l}- \\
-\end{array}$ \\
\hline
\end{tabular}


Table 4. Univariate and multivariate logistic regression analyses of factors associated with pelvic LN metastasis

\begin{tabular}{|c|c|c|}
\hline Variables & $\mathrm{HR}(95 \% \mathrm{Cl})$ & $P$-value \\
\hline \multicolumn{3}{|c|}{ Univariate analysis, $n=105$} \\
\hline $\begin{array}{l}\text { Age (years) } \\
\text { Tumour size }(\mathrm{cm})\end{array}$ & $\begin{array}{l}0.976(0.919-1.037) \\
1.768(1.219-2.564)\end{array}$ & $\begin{array}{l}0.428 \\
0.003\end{array}$ \\
\hline Differentiation & & 0.963 \\
\hline $\begin{array}{l}\text { G1 (reference) } \\
\text { G2 } \\
\text { G3 }\end{array}$ & $\begin{array}{c}1 \\
1.379(0.140-13.556) \\
1.327(0.142-12.366)\end{array}$ & $\begin{array}{l}0.783 \\
0.804\end{array}$ \\
\hline FIGO stage & & 0.116 \\
\hline $\begin{array}{l}\text { I (reference) } \\
\text { II }\end{array}$ & $\begin{array}{c}1 \\
2.174(0.826-5.718)\end{array}$ & \\
\hline LVSI & & $<0.001$ \\
\hline $\begin{array}{l}\text { Negative (reference) } \\
\text { Positive }\end{array}$ & $\begin{array}{c}1 \\
23.700(6.402-87.741)\end{array}$ & \\
\hline Stromal invasion & & 0.006 \\
\hline $\begin{array}{l}\leqslant 1 / 2 \text { (reference) } \\
>1 / 2\end{array}$ & $\begin{array}{c}1 \\
5.077(1.582-16.293)\end{array}$ & \\
\hline Parametrial invasion & & 0.348 \\
\hline $\begin{array}{l}\text { Negative (reference) } \\
\text { Positive }\end{array}$ & $\begin{array}{c}1 \\
2.026(0.464-8.849)\end{array}$ & \\
\hline Vaginal invasion & & 0.214 \\
\hline $\begin{array}{l}\text { Negative (reference) } \\
\text { Positive }\end{array}$ & $\begin{array}{c}1 \\
2.019(0.666-6.123)\end{array}$ & \\
\hline MnSOD & & 0.011 \\
\hline $\begin{array}{l}\text { Low (reference) } \\
\text { High }\end{array}$ & $\begin{array}{c}1 \\
3.551(1.342-9.399)\end{array}$ & \\
\hline HspB1 & & 0.001 \\
\hline $\begin{array}{l}\text { Low (reference) } \\
\text { High }\end{array}$ & $\begin{array}{c}1 \\
5.59(2.020-15.468)\end{array}$ & \\
\hline FABP5 & & $<0.001$ \\
\hline $\begin{array}{l}\text { Low (reference) } \\
\text { High }\end{array}$ & $\begin{array}{c}1 \\
6.750(2.413-18.880)\end{array}$ & \\
\hline
\end{tabular}

Multivariate analysis ${ }^{a}, n=105$

\begin{tabular}{|c|c|c|}
\hline LVSI & & 0.001 \\
\hline Negative (reference) & 1 & \\
\hline Positive & $17.512(3.181-96.420)$ & \\
\hline Stromal invasion & & 0.074 \\
\hline$\leqslant 1 / 2$ (reference) & 1 & \\
\hline$>1 / 2$ & $4.038(0.872-18.701)$ & \\
\hline HspB1 & & 0.013 \\
\hline Low (reference) & 1 & \\
\hline High & $6.379(1.480-27.482)$ & \\
\hline FABP5 & & 0.018 \\
\hline Low (reference) & 1 & \\
\hline High & $5.829(1.355-25.075)$ & \\
\hline MnSOD & & 0.053 \\
\hline Low (reference) & 1 & \\
\hline High & $4.053(0.980-16.769)$ & \\
\hline
\end{tabular}

Abbreviations: $95 \% \mathrm{Cl}=95 \%$ confidence interval; $\mathrm{FIGO}=$ the International Federation of Gynaecology and Obstetrics; HR= hazard ratio; LVSI = lymphovascular space invasion. ${ }^{a}$ For the stepwise multivariate analysis, backward LR method was used to drop insignifican variables. Variables entered for analysis were the following: age, tumour size, differentiation, FIGO stage, LVSI, stomal invasion, parametrial invasion, vaginal invasion, FABP5, HspB1, and $\mathrm{MnSOD}$
To assess the discriminatory power for the three proteins to predicting PLNM in CC, I-IIst, ROC curves were constructed (Figure 2C). The three proteins were used as covariates to create a logistic regression model with PLNM as the dependent variable. As a result, we could further evaluate the feasibility of the combination of FABP5, HspB1, and MnSOD to predicting PLNM. The area under the ROC curve (AUC), sensitivity, specificity, positive predictive value (PPV), and negative predictive value (NPV) for FABP5, HspB1, MnSOD, and the combination of the three proteins are shown in Table 5. The cut-points (by maximising the Youden index) of FABP5, HspB1, MnSOD, and the combination of the three proteins were $3,5,3$, and 0.2448 (predicted probability from the logistic regression model of combining the three proteins), respectively. When all three proteins were considered, the discriminatory power was strong $(\mathrm{AUC}=0.929)$.

Correlations of FABP5, HspB1, and MnSOD expression with postoperative relapse and survival. At the end of the study, 34 patients (32.38\%) experienced disease recurrence, 31 patients (29.53\%) had died of CC, I-IIst, and 74 patients (70.48\%) were still alive. The relapse-free probability curves indicated that the relapse rate increased significantly with upregulation of FABP5, HspB1, and MnSOD (Figure 3). The survival curves indicated that the overall survival rate decreased significantly with upregulation of FABP5, HspB1, and MnSOD (Figure 3).

\section{DISCUSSION}

PLNM is an important prognostic factor in CC, I-IIst, and PLN status is crucial to decision-making about personalised treatment of CC, I-IIst. Currently, it is difficult to diagnose PLNM accurately and efficiently in usual assessment methods used for CC, I-IIst before first treatment. Therefore, reliable biomarkers for clinical diagnosis and better insights into the pathogenesis of PLNM in CC, I-IIst are needed. Our results suggest that FABP5, HspB1, and MnSOD may predict PLNM in CC, I-IIst patients and may also provide information useful to help further elucidate the molecular mechanisms underlying PLNM in CC, I-IIst.

In this study, first, we identified 41 differential proteins between primary early-stage cervical squamous cell cancer tissue with and without PLNM using DIGE-based proteomics. These proteins participate in processes of malignancy progression and metastasis, such as oxidative stress, energy metabolism, cytoskeleton reorganisation, and signal transduction. Second, three differential proteins (FABP5, HspB1, and MnSOD) were validated by western blotting and IHC, indicating that the proteins identified by the proteomic approach were actually differentially expressed proteins. Finally, correlations of the expression levels of the three proteins with clinicopathological factors and clinical outcomes were evaluated in an independent tissue cohort. Our data indicated that FABP5, HspB1, and MnSOD were significantly correlated with PLNM and poor prognosis.

FABP5 is a member of the fatty acid binding protein family with functions in fatty acid uptake, metabolism, and transportation. FABP5 is highly expressed in several types of tumours, such as prostate (Adamson et al, 2003), oral (Fang et al, 2010), and hepatocellular carcinomas (Fujii et al, 2005). In addition, accumulative studies have shown that upregulation of FABP5 is correlated with tumour metastasis (Fang et al, 2010; Jeong et al, 2012). Previous studies reported that overexpression of FABP5 induces metastasis by upregulating vascular endothelial growth factor (VEGF) (Jing et al, 2001) and matrix metalloproteinase 9 (MMP-9) (Fang et al, 2010), which has important roles in the metastatic progression. To our knowledge, there are currently no published reports on the expression of FABP5 in cervical cancer. This study, for the first time, showed that FABP5 was higher expressed in PLNM CC, I-IIst 
Table 5. Sensitivity, specificity, AUC, positive-, and negative-predictive values of factors associated with pelvic LN metastasis

\begin{tabular}{|l|c|c|c|c|c|}
\hline Factors & Sensitivity (95\% Cl) (\%) & Specificiy (95\% Cl) (\%) & PPV (95\% Cl) (\%) & NPV (95\% Cl) (\%) & AUC (95\% Cl) \\
\hline HspB1 & $54.55(32.2-75.6)$ & $95.18(88.1-98.7)$ & $75(47.6-92.7)$ & $88.8(80.3-94.5)$ & $0.803(0.714-0.874)$ \\
\hline FABP5 & $68.18(45.1-86.1)$ & $75.9(65.3-84.6)$ & $42.9(26.3-60.6)$ & $90(80.5-95.9)$ & $0.761(0.668-0.839)$ \\
\hline MnSOD & $63.64(40.7-82.8)$ & $74.7(64.0-83.6)$ & $40(23.9-57.9)$ & $88.6(78.7-94.9)$ & $0.713(0.616-0.797)$ \\
\hline HspB1 + FABP5 + MnSOD & $86.36(65.1-97.1)$ & $85.54(76.1-92.3)$ & $61.3(42.2-78.2)$ & $95.9(88.5-99.2)$ & $0.929(0.862-0.970)$ \\
\hline
\end{tabular}
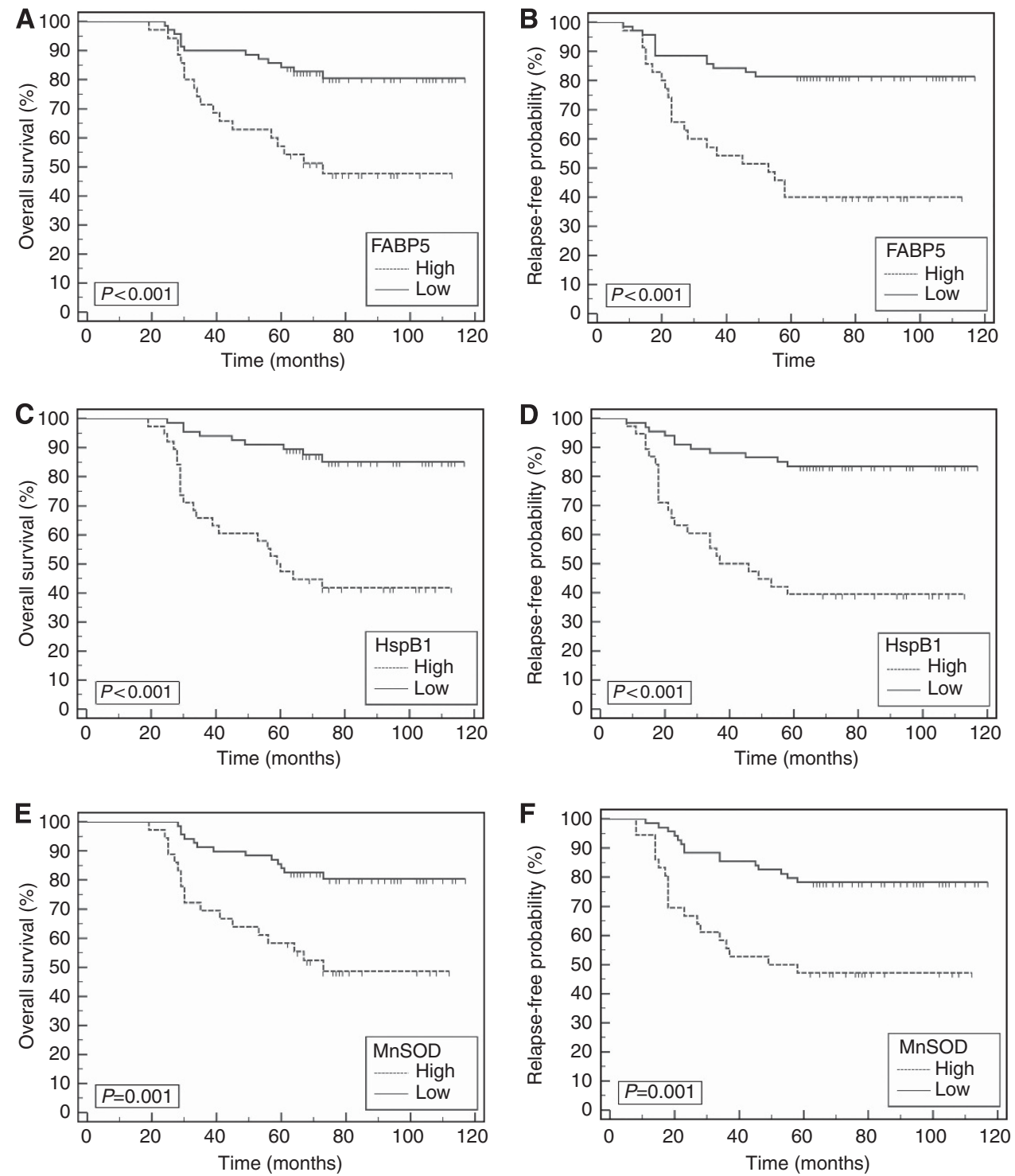

Figure 3. Kaplan-Meier survival plots for early-stage cervical cancer according to the expression levels of FABP5, HspB1, and MnSOD.

(A) FABP5 expression and overall survival (log-rank test, $P<0.001$ ). (B) FABP5 expression and relapse-free probability (log-rank test, $P<0.001)$. (C) HspB1 expression and overall survival (log-rank test, $P<0.001$ ). (D) HspB1 expression and relapse-free probability (log-rank test, $P<0.001$ ).

(E) MnSOD expression and overall survival (log-rank test, $P=0.001$ ). (F) MnSOD expression and relapse-free probability (log-rank test, $P=0.001)$.

tissue than NPLNM CC, I-IIst tissue and that its upregulation was significantly correlated with PLNM $(P<0.001)$ and poor prognosis $(P<0.001)$. Moreover, the results showed that FABP5 was an independent predictor $(P=0.018)$ for CC, I-IIst patients with PLNM in multivariate analysis. Thus, FABP5 may be a biomarker for predicting PLNM of CC, I-IIst. It seems that FABP5 upregulation has a role in the development of PLNM.
HspB1 acts as a molecular chaperone whose main function is to prevent the aggregation of misfolded proteins and to restore denatured proteins. Its functions can be triggered by different types of stress such as inflammation, oxidative stress, and malignant transformation (Ciocca and Calderwood, 2005). HspB1 is overexpressed in several types of malignancies (Huang et al, 2010; Yu et al, 2010) and has been correlated with poor prognosis ( $\mathrm{Yu}$ et al, 2010). 

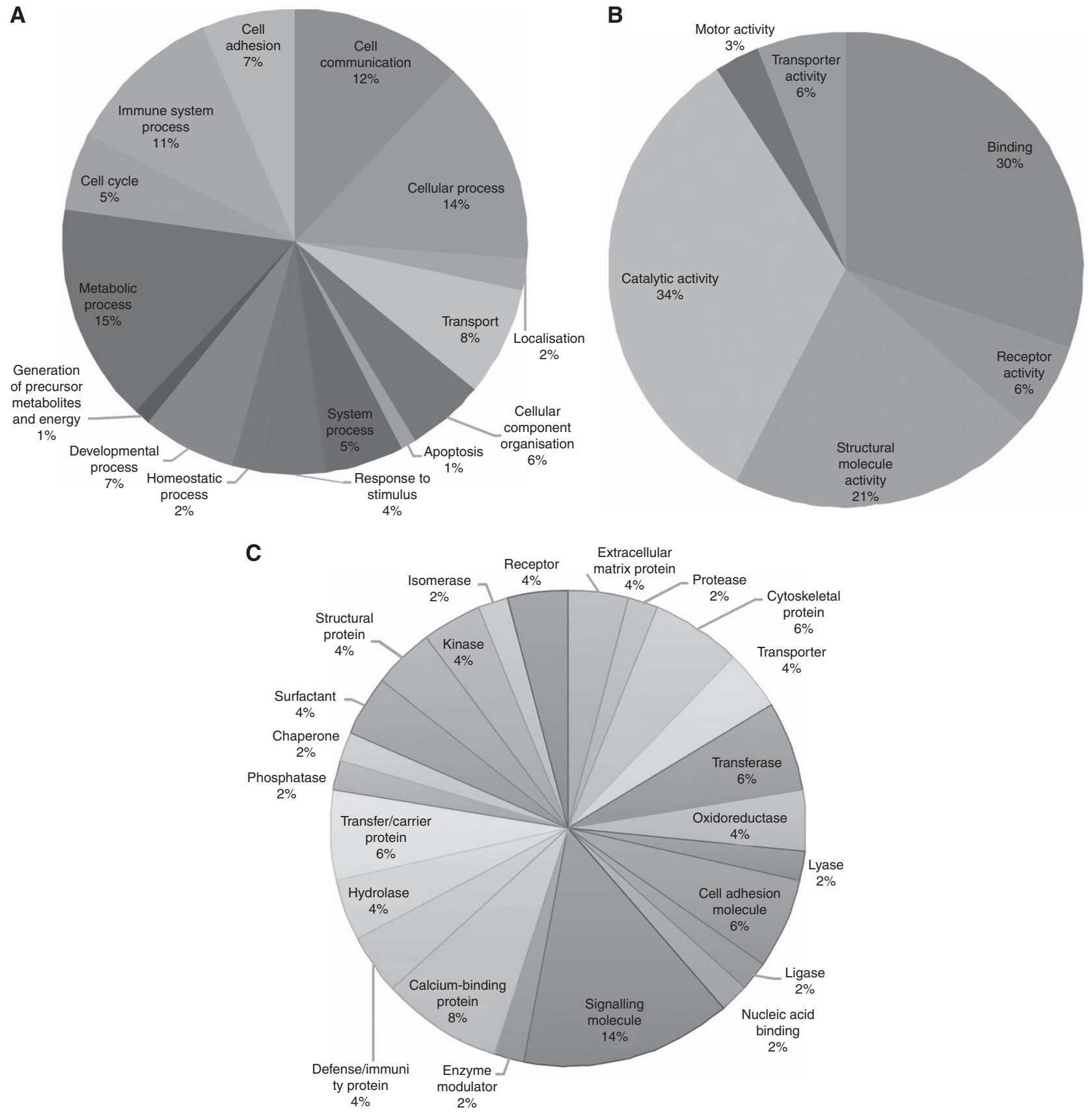

Figure 4. Classification analysis of differentially expressed proteins in early-stage cervical cancer with and without PLNM. (A) Classification of the differential proteins according to biological process. (B) Classification of the differential proteins according to molecular function. (C) Classification of the differential proteins according to protein class.

Moreover, it has been reported that upregulation of HspB1 is associated with tumour metastasis (Nagaraja et al, 2012). In cervical cancer, the correlation of $\mathrm{HspB} 1$ overexpression with carcinogenesis has been shown (Ono et al, 2009; Lomnytska et al, 2011), but has not yet been associated with PLNM. Our study revealed a significant association of HspB1 expression with PLNM $(P<0.001)$ and that $\mathrm{HspB1}$ was an independent predictor of PLNM in multivariate analysis $(P=0.013)$. Thus, our data suggest that HspB1 may be a biomarker of PLNM for CC, I-IIst and that upregulation of HspB1 may be involved in the development of PLNM in CC, I-IIst. Additionally, our data showed that patients with HspB1 upregulation had a poor prognosis. However, a previous study showed that cervical cancer patients (FIGO stage Ib1-IIIb) with low $(n=2)$ or high HspB1 $(n=4)$ expression levels had poorer prognoses than patients with moderate protein expression levels $(n=8)$ (Lomnytska et al, 2011). The different results between these two studies may be due to different sample cohorts and sample quantities (105 samples versus 14 samples).

$\mathrm{MnSOD}$ (also called $\mathrm{SOD}_{2}$ ) is localised to the mitochondria and can catalyse the superoxide radical $\left(\mathrm{O}_{2}^{-}\right)$to $\mathrm{H}_{2} \mathrm{O}_{2}$ and hydroperoxides. $\mathrm{H}_{2} \mathrm{O}_{2}$ and hydro-peroxides then promote oxidative stress, which contributes to tumour progression and metastasis (Sotgia et al, 2011). MnSOD has attracted the attention of many investigators because of its overexpression in various types of human malignancies such as colorectal (Nozoe et al, 2003), gastric (Malafa et al, 2000), and oral squamous cell carcinomas (Liu et al, 2010), and it is often associated with metastatic progression (Malafa et al, 2000; Liu et al, 2010). Additionally, some studies have shown that MnSOD-dependent upregulation of MMPs (including MMP-1 and MMP-9) may contribute to the increased invasive and 
metastatic capacities of tumours (Nelson et al, 2003). In cervical cancer, a correlation of MnSOD upregulation with different stages of cancer was shown (Termini et al, 2011), but there is no report of studying its association with PLNM. Our study showed a significant correlation between MnSOD expression and PLNM $(P=0.006)$, which is consistent with previous studies in other tumours (Nozoe et al, 2003; Liu et al, 2010). Additionally, we found that MnSOD was a significant predictor of PLNM $(P=0.011)$ in the univariate analysis. In the multivariate analysis, MnSOD trended towards being an independent predictor of PLNM $(P=0.053)$, but the differences did not reach statistical significance. This result may be due to the study's relatively small sample size, which affects statistical power. Therefore, our data suggest that MnSOD may be a biomarker for PLNM of CC, I-IIst, and upregulation of MnSOD may support the development of PLNM in CC, I-IIst.

Surgery as a treatment option for CC, I-IIst can offer hope of fertility or function preservation and avoid the damage of ovary and vagina function. Therefore, surgical treatment is a much better option for patients without PLNM and with desire for fertility or function preservation. For patients with PLNM and with desire for function preservation, surgical treatment also can be considered because the normal ovaries can be transposed during the surgery, so that the ovaries will not be damaged by postoperative radiotherapy. For patients with PLNM and without desire for function preservation, chemoradiotherapy should be recommended as the first treatment to avoid the morbidity caused by combining surgery and chemoradiotherapy. In the present study, the combination of FABP5, HspB1, and MnSOD had a good discrimination power $(A U C=0.929)$, high sensitivity and specificity $(86.36 \%$ and $85.54 \%$, respectively), high NPV (95.7\%), and moderate PPV (61.3\%) for the identification of CC, I-IIst patients with PLNM. These test characteristics are based on the decision to use 0.2448 (by maximising the Youden index) as a cut-point. Because of the high NPV, these proteins can be helpful in the clinical decision-making process. If a patient has a NPLNM diagnosed by the combination of these proteins (cutpoint $=0.2448, \mathrm{NPV}=95.7 \%$ ), then the clinician can plan surgery (fertility preservation or function preservation) for patients, which depends on the patient's desire. If a patient has a PLNM diagnosed by the combination of these proteins (cut-point $=0.654$, by maximising PPV to $92.3 \%$ ), then the clinician can recommend chemoradiotherapy or function preservation surgery (plus postoperative adjuvant therapy) for patients, which depends on the patient's desire. As primary cervical cancer tissues can be easily obtained by transvaginal biopsy for detecting the expression levels of these proteins before treatment, these proteins can be applied to evaluate PLNM for CC, I-IIst patients before the first management.

Consistent with previous studies (Pallavi et al, 2012), our results revealed that LVSI was also an independent predictor of PLNM. When comparing PLNM prediction capacities, we observed that the AUCs of HspB1 (0.803) and FABP5 (0.761) were higher than the AUC of LVSI (0.749). Additionally, when combining FABP5, $\mathrm{HspB} 1$, and MnSOD, we found that the discriminatory power was significantly improved (Figure 4). The AUC of LVSI (0.749) was much lower than that of the combination of the three proteins (0.929). These findings suggest that FABP5, HspB1, and MnSOD may be promising biomarker candidates for identifying CC, I-IIst patients with PLNM.

Previous studies have shown that stromal invasion is an important predictor of PLNM in cervical cancer (Gauthier et al, 1985; Ayhan et al, 1991). In our study, univariate analysis showed that stromal invasion was a significant predictor of PLNM $(P=0.006)$. However, in multivariate analysis, it was not an independent predictor of PLNM $(P=0.074)$. This may be due to the small sample size, which is a main limitation of our study.
The reason for the small sample size was that only patients without preoperative adjuvant therapy and with complete follow-up data were eligible to be enrolled in our study. Moreover, the incidence of PLNM in CC, I-IIst is low. Therefore, the sample size of this study was relatively small. Another limitation of the present study is that only one pathological type of cervical cancer (squamous cell cancer) was studied. This was because of the need for homogenous samples in proteomic analysis. On the other hand, the prevalence of other pathological types of cervical cancer is low so that we could not collect enough tumour samples for the study. Thus future studies with larger sample sizes and different pathological types need to be performed.

In summary, we identified 41 differentially expressed proteins between primary CC, I-IIst tissues with and without PLNM using DIGE-based proteomics. We further found that three differentially expressed proteins (FABP5, HspB1, and MnSOD) are potential biomarkers for PLNM of CC, I-IIst, and may contribute to the pathogenesis of PLNM. These findings may help clinicians to design optimal individualised treatment plans before first treatment.

\section{ACKNOWLEDGEMENTS}

This study was funded by the Sun Yat-sen University Clinical Research 5010 Program (Grant number 2007010) and the Guangdong Natural Science Fund (Grant number S2013010015448).

\section{CONFLICT OF INTEREST}

The authors declare no conflict of interest.

\section{REFERENCES}

Adamson J, Morgan EA, Beesley C, Mei Y, Foster CS, Fujii H, Rudland PS, Smith PH, Ke Y (2003) High-level expression of cutaneous fatty acid-binding protein in prostatic carcinomas and its effect on tumorigenicity. Oncogene 22(18): 2739-2749.

Ayhan A, Tuncer ZS, Kucukali T, Tuna T, Enunlu T (1991) Correlation between pathological risk factors and pelvic lymph node metastases in stage I squamous carcinoma of the cervix: a multivariate analysis of 194 cases. J Surg Oncol 48(3): 207-209.

Cao DY, Yang JX, Wu XH, Chen YL, Li L, Liu KJ, Cui MH, Xie X, Wu YM, Kong BH, Zhu GH, Xiang Y, Lang JH, Shen K (2013) Comparisons of vaginal and abdominal radical trachelectomy for early-stage cervical cancer: preliminary results of a multi-center research in China. Br J Cancer 109(11): 2778-2782.

Cheng AL, Huang WG, Chen ZC, Peng F, Zhang PF, Li MY, Li F, Li JL, Li C, Yi H, Yi B, Xiao ZQ (2008) Identification of novel nasopharyngeal carcinoma biomarkers by laser capture microdissection and proteomic analysis. Clin Cancer Res 14(2): 435-445.

Choi HJ, Roh JW, Seo SS, Lee S, Kim JY, Kim SK, Kang KW, Lee JS, Jeong JY, Park SY (2006) Comparison of the accuracy of magnetic resonance imaging and positron emission tomography/computed tomography in the presurgical detection of lymph node metastases in patients with uterine cervical carcinoma: a prospective study. Cancer 106(4): 914-922.

Chou HH, Chang TC, Yen TC, Ng KK, Hsueh S, Ma SY, Chang CJ, Huang HJ, Chao A, Wu TI, Jung SM, Wu YC, Lin CT, Huang KG, Lai CH (2006) Low value of [18F]-fluoro-2-deoxy-D-glucose positron emission tomography in primary staging of early-stage cervical cancer before radical hysterectomy. J Clin Oncol 24(1): 123-128.

Ciocca DR, Calderwood SK (2005) Heat shock proteins in cancer: diagnostic, prognostic, predictive, and treatment implications. Cell Stress Chaperones 10(2): 86-103.

Fang LY, Wong TY, Chiang WF, Chen YL (2010) Fatty-acid-binding protein 5 promotes cell proliferation and invasion in oral squamous cell carcinoma. J Oral Pathol Med 39(4): 342-348. 
Fujii K, Kondo T, Yokoo H, Yamada T, Iwatsuki K, Hirohashi S (2005) Proteomic study of human hepatocellular carcinoma using two-dimensional difference gel electrophoresis with saturation cysteine dye. Proteomics 5(5): 1411-1422.

Gauthier P, Gore I, Shingleton HM, Soong SJ, Orr JJ, Hatch KD (1985) Identification of histopathologic risk groups in stage IB squamous cell carcinoma of the cervix. Obstet Gynecol 66(4): 569-574.

Gien LT, Covens A (2009) Lymph node assessment in cervical cancer: prognostic and therapeutic implications. J Surg Oncol 99(4): 242-247.

Huang L, Lin JX, Yu YH, Zhang MY, Wang HY, Zheng M (2012) Downregulation of six microRNAs is associated with advanced stage, lymph node metastasis and poor prognosis in small cell carcinoma of the cervix. PLoS One 7(3): e33762.

Huang L, Zheng M, Zhou QM, Zhang MY, Jia WH, Yun JP, Wang HY (2011) Identification of a gene-expression signature for predicting lymph node metastasis in patients with early stage cervical carcinoma. Cancer 117(15): 3363-3373.

Huang Q, Ye J, Huang Q, Chen W, Wang L, Lin W, Lin J, Lin X (2010) Heat shock protein 27 is over-expressed in tumor tissues and increased in sera of patients with gastric adenocarcinoma. Clin Chem Lab Med 48(2): 263-269.

Jemal A, Bray F, Center MM, Ferlay J, Ward E, Forman D (2011) Global cancer statistics. CA Cancer J Clin 61(2): 69-90.

Jeong CY, Hah YS, Cho BI, Lee SM, Joo YT, Jung EJ, Jeong SH, Lee YJ, Choi SK, Ha WS, Park ST, Hong SC (2012) Fatty acid-binding protein 5 promotes cell proliferation and invasion in human intrahepatic cholangiocarcinoma. Oncol Rep 28(4): 1283-1292.

Jing C, Beesley C, Foster CS, Chen H, Rudland PS, West DC, Fujii H, Smith PH, Ke Y (2001) Human cutaneous fatty acid-binding protein induces metastasis by up-regulating the expression of vascular endothelial growth factor gene in rat Rama 37 model cells. Cancer Res 61(11): 4357-4364.

Kim TJ, Choi JJ, Kim WY, Choi CH, Lee JW, Bae DS, Son DS, Kim J, Park BK, Ahn G, Cho EY, Kim BG (2008) Gene expression profiling for the prediction of lymph node metastasis in patients with cervical cancer. Cancer Sci 99(1): 31-38.

Kobayashi Y, Akiyama F, Hasumi K (2006) A case of successful pregnancy after treatment of invasive cervical cancer with systemic chemotherapy and conization. Gynecol Oncol 100(1): 213-215.

Landoni F, Maneo A, Colombo A, Placa F, Milani R, Perego P, Favini G, Ferri L, Mangioni C (1997) Randomised study of radical surgery versus radiotherapy for stage Ib-IIa cervical cancer. Lancet 350(9077): 535-540.

Langley RR, Fidler IJ (2011) The seed and soil hypothesis revisited-the role of tumor-stroma interactions in metastasis to different organs. Int J Cancer 128(11): 2527-2535.

Li Y, Wu J, Zhang W, Zhang N, Guo H (2013) Identification of serum CCL15 in hepatocellular carcinoma. Br J Cancer 108(1): 99-106.

Liu X, Wang A, Lo ML, Kolokythas A, Sheng S, Rubini C, Ye H, Shi F, Yu T, Crowe DL, Zhou X (2010) Deregulation of manganese superoxide dismutase (SOD2) expression and lymph node metastasis in tongue squamous cell carcinoma. BMC Cancer 10: 365.

Lomnytska MI, Becker S, Bodin I, Olsson A, Hellman K, Hellstrom AC, Mints M, Hellman U, Auer G, Andersson S (2011) Differential expression of ANXA6, HSP27, PRDX2, NCF2, and TPM4 during uterine cervix carcinogenesis: diagnostic and prognostic value. Br J Cancer 104(1): 110-119.

Malafa M, Margenthaler J, Webb B, Neitzel L, Christophersen M (2000) MnSOD expression is increased in metastatic gastric cancer. J Surg Res 88(2): 130-134.

Nagaraja GM, Kaur P, Asea A (2012) Role of human and mouse HspB1 in metastasis. Curr Mol Med 12(9): 1142-1150.
Nelson KK, Ranganathan AC, Mansouri J, Rodriguez AM, Providence KM, Rutter JL, Pumiglia K, Bennett JA, Melendez JA (2003) Elevated sod2 activity augments matrix metalloproteinase expression: evidence for the involvement of endogenous hydrogen peroxide in regulating metastasis. Clin Cancer Res 9(1): 424-432.

Nozoe T, Honda M, Inutsuka S, Yasuda M, Korenaga D (2003) Significance of immunohistochemical expression of manganese superoxide dismutase as a marker of malignant potential in colorectal carcinoma. Oncol Rep 10(1): $39-43$.

Ono A, Kumai T, Koizumi H, Nishikawa H, Kobayashi S, Tadokoro M (2009) Overexpression of heat shock protein 27 in squamous cell carcinoma of the uterine cervix: a proteomic analysis using archival formalin-fixed, paraffin-embedded tissues. Hum Pathol 40(1): 41-49.

Pallavi VR, Devi KU, Mukherjee G, Ramesh C, Bafna UD (2012) Relationship between lymph node metastases and histopathological parameters in carcinoma cervix: a multivariate analysis. J Obstet Gynaecol 32(1): 78-80.

Pang J, Liu WP, Liu XP, Li LY, Fang YQ, Sun QP, Liu SJ, Li MT, Su ZL, Gao X (2010) Profiling protein markers associated with lymph node metastasis in prostate cancer by DIGE-based proteomics analysis. J Proteome Res 9(1): $216-226$.

Plante M, Renaud MC, Tetu B, Harel F, Roy M (2003) Laparoscopic sentinel node mapping in early-stage cervical cancer. Gynecol Oncol 91(3): 494-503.

Rob L, Pluta M, Strnad P, Hrehorcak M, Chmel R, Skapa P, Robova H (2008) A less radical treatment option to the fertility-sparing radical trachelectomy in patients with stage I cervical cancer. Gynecol Oncol 111(2 Suppl): S116-S120.

Selman TJ, Mann C, Zamora J, Appleyard TL, Khan K (2008) Diagnostic accuracy of tests for lymph node status in primary cervical cancer: a systematic review and meta-analysis. CMAJ 178(7): 855-862.

Sotgia F, Martinez-Outschoorn UE, Lisanti MP (2011) Mitochondrial oxidative stress drives tumor progression and metastasis: should we use antioxidants as a key component of cancer treatment and prevention? BMC Med 9: 62.

Termini L, Filho AL, Maciag PC, Etlinger D, Alves VA, Nonogaki S, Soares FA, Villa LL (2011) Deregulated expression of superoxide dismutase-2 correlates with different stages of cervical neoplasia. Dis Markers 30(6): $275-281$.

van de Lande J, von Mensdorff-Pouilly S, Lettinga RG, Piek JM, Verheijen RH (2012) Open versus laparoscopic pelvic lymph node dissection in early stage cervical cancer: no difference in surgical or disease outcome. Int J Gynecol Cancer 22(1): 107-114.

Van Gorp T, Cadron I, Daemen A, De Moor B, Waelkens E, Vergote I (2012) Proteomic biomarkers predicting lymph node involvement in serum of cervical cancer patients. Limitations of SELDI-TOF MS. Proteome Sci 10(1): 41.

Vercellino GF, Piek JM, Schneider A, Kohler C, Mangler M, Speiser D, Chiantera V (2012) Laparoscopic lymph node dissection should be performed before fertility preserving treatment of patients with cervical cancer. Gynecol Oncol 126(3): 325-329.

Yu Z, Zhi J, Peng X, Zhong X, Xu A (2010) Clinical significance of HSP27 expression in colorectal cancer. Mol Med Rep 3(6): 953-958.

This work is published under the standard license to publish agreement. After 12 months the work will become freely available and the license terms will switch to a Creative Commons AttributionNonCommercial-Share Alike 3.0 Unported License.

Supplementary Information accompanies this paper on British Journal of Cancer website (http://www.nature.com/bjc) 